FACTA UNIVERSITATIS

Series: Economics and Organization Vol. 14, N ${ }^{\mathrm{o}} 2$, 2017, pp. 175 - 187

DOI: $10.22190 /$ FUEO1702175D

Preliminary Communication

\title{
ICT ENABLED IMPLEMENTATION OF STRATEGY - EMPIRICAL EVIDENCE FROM SERBIAN CUSTOMS SERVICE
}

\author{
UDC 004:007]:339.543(497.11)
}

\author{
Sanja Dalton* \\ Univeristy of Belgrade, Faculty of Organizational Sciences, Belgrade, Serbia
}

\begin{abstract}
In this paper ICT enabled implementation of Serbian Customs Service Strategy is presented. The aim of the research is to measure and analyze the impact of ICT on successful implementation of the Organization's Strategy. The research was conducted by survey -questionnaires and personal interviews with the Customs Service Senior Management and Top Managers. The data was also collected by using secondary data (customs reports). The results show that the new computerized system has a positive impact on key performance indicators improvement that is the core goal of the Strategy.
\end{abstract}

Key words: strategy, information and communication technology, strategic management

JEL Classification: M10, M15, M16

\section{INTRODUCTION}

The Customs Administration of Serbia operates on the basis on consecutive strategies implemented in connection with significant external challenges, such as accession of the Republic of Serbia to the European Union. According to Torma (2011), the main features of the European Administrative Space are a stable, competent, highly qualified and neutral civil service (civil servant). At present, economic, budgetary and technological conditions are becoming particularly important. The Customs Service is seeking to increase its effectiveness through the application of strategic management methods and supporting information technology. To some authors, "Creating a technology plan is an opportunity for an organization to focus on its mission, goals and strategies" (Podolsky, 2003, p. 5). Rapid economic progress in the economy fosters innovations in public administrations. Therefore, the economic and

Received December 26, 2016 / Accepted March 28, 2017

Corresponding author: Sanja Dalton,

*Candidate of Ph.D in Management. Ms.C (MBA) graduate

The Faculty of Organizational Sciences, Belgrade, Serbia

E-mail: sanjadalton78@gmail.com 
technological conditions will affect the expectations of stakeholders consisting of clients, the budget, society, legislators, partners, suppliers, as well as management staff, customs officers and employees of the Customs Service, towards the Customs Service. According to Cole (2006), understanding the external environment of business, economic, technological, social and political influences is crucial to strategic decision-makers.

The Business Strategy of the Serbian Customs Service through implementation of the New Customs Transit System (NCTS) as a new ICT system will enable and foster active international cooperation, in particular, with the European Union and in bilateral contacts with neighboring states. For some authors, "Organizations which want to maintain a competitive advantage have to be ready to adopt and adapt technological developments in administrative procedures to stay ahead" (Cole, 2006, p. 31). This refers, in particular, combating customs and fiscal crime, the EU Customs Union, regional cooperation and the initiatives at the World Customs Organization. The Strategy of the Serbian Customs Administration through the implementation of the new ICT system shall ensure:

The Mission The Customs Service, acting for the benefit of the Republic of Serbia and its society:

- Collects customs duties and taxes effectively,

- Actively supports business activities,

- Combat customs fraud effectively and protects markets and society.

The Mission reflects the role of the Customs Service in relation to its stakeholders and responds to their key needs. "All organizations exist to serve one or more interests outside themselves. Most, in fact, have relationships, with range of interested parties or 'stakeholders"' (Cole, 2006, p. 13).

The Vision Using knowledge innovatively to provide better service in the digital lifestyle era through application of comprehensive approach to clients that enhance the quality of service provided with better exploitation of recourses, including IT resources.

The Strategic Objectives As an organization, the Customs Service aims at the highest possible levels of cooperation with the environment adjusting the needs of the direct beneficiaries of its services. According to Cole (2006) objectives are the organizations operational targets and respond to changes in its stakeholders relationships.

The Strategic Goals The formulation of the strategic goals stems from the current and future expectations of the strategic stakeholders of the Customs Service, clients, the budget and the society.

"The overlapping area between Strategy and operations is an important aspect of the relationship between the two dimensions of management activity. According to some authors, this overlap acts as a bridging stage between key decisions about Strategy and their actual implementation throughout the operational units of the business" (Cole, 2006, p. 10).

This paper consists of five parts. The first part is the Introduction to the research. The second part consists of the literature review regarding the Strategic Management in Public Organizations and Implementation of ICT based Strategy of the Organization. The third part is reserved for research methodology. The fourth part consists of results and the discussion on results of the research, that confirm the Hypothesis that the implemented Strategy based on ICT improved the operational activities (KPIs) of the Service. Finally, in the fifth part the conclusion of the research is presented. 


\section{LITERATURE REVIEW}

\subsection{The concept of strategic management in public organizations}

To some authors, "One of the most important elements in managing a successful organization is having a sense of strategy" (Bouman, 2003, p. 1). For Lumpkin et al., (2007) strategic managers who apply proactive approach always look forward to the future in searching for new opportunities for growth and development of an organization. "Strategic management in public organizations is about achieving success for the organization by achieving the stated purpose, goal and objectives promulgated by the top management. This is not the only measure of success, but it is fundamental one" (Cole, 2006, p. 15). The mission, vision and strategy of a public organization play an important role in the expression of its identity, the position it takes on the issues it faces, and its future direction. "A vision that is made in vacuum, and that is not in compliance with the environmental threats or convenient opportunities, or with resources and capability of the organization itself, can ignore the real needs of an organization. Thus, if the vision is not based on the reality, the employees will reject it. A corporate vision is a start position (the initial starting point) for setting up clear targets hierarchy. Vision is mainly described as a final target that is "strongly inspiring, comprehensive and long-lasting" (Lumpkin et al., 2007, p. 29). As an addition, a vision cannot be considered a magic remedy for an organization's diseases. An idealistic vision can make the employees enthusiastic, but the employees' enthusiasm could be easily smothered if they realize that the managers do not act in accordance with the vision (Lumpkin et al., 2007). For Lumpkin et al (2007), well formulated Mission Statement includes the concept of stakeholders' management, thus points out that organization must meet the needs of various groupings in order to survive and prosper. Strategic goals of a public organization are used in order for mission statements to become operational. In other words, they give guidelines to a company how to fulfill its "higher targets" in the targets hierarchy that are vision and mission (Chatterjee, 2005). The goals must meet a few criteria in order to be sensible. According to Chatterjee (2005), the strategic goals must be: measurable (there must be at least one parameter that measures the level of advancement towards the desired goal), adequate (the goals must be in line with the vision and mission of the organization), realistic (the goals must be attractive but also feasible), time-wise determined (there must be a time frame for the realization of the goals). Mission and vision must be in line with strategic goals of a public organization! For some authors, the key goals and aims of a public organization usually embrace the major units or functions at the organizations. These goals or aims are usually intended to provide for the medium term. On the other hand, objectives are the organization's operational targets, usually for period of one year or less and it responds to changes in its stakeholders relationships (Cole, 2006). According to Lumpkin et al (2007), strategic management has four key attributes: 1. Oriented toward comprehensive goals of an organization, 2. includes various stakeholders, 3. encompasses both short-term and long-term perspectives, 4. encompasses a compromise between effectiveness and efficiency. Strategic managers in public organizations nowadays mainly deal with three (interconnected) factors, such as: globalization, technology and intellectual capital. The second essence of the strategic management is analysis of the problem related to why some companies are more successful than the others (Lu \& Beamish, 2004). For Michael Porter, the competition advantage could be realized only 
through operational effectiveness (Gupta \& Govindarajan, 2001). According to some authors, majority of popular innovations that were introduced by managers during the last twenty years, such as: total quality, business process reengineering, just-in-time, benchmarking are related to operational effectiveness. Operational effectiveness presumes that the actions are performed in a better way than the competitors. Companies have to ensure means in order to focus on their innovative projects. By defining a "strategic envelope", companies protect their innovative ideas to be directed toward uncertain projects. Thus, companies have to not only define the type of innovation they are expecting, but also the expected results (Lumpkin et al., 2007).

According to Stross (1997), there are four key attributes of strategic management:

1. Firstly, strategic management is oriented toward overall targets and tasks of an organization. Some authors consider this attribute "organization vs. individual rationality".

2. Strategic management implies taking the stakeholders into consideration during the decision-taking process. Managers must take demands of numerous stakeholders into consideration during the decision-making. Strategic management requires inclusion of short-term and long-term perspective. For some authors that is "creative tension" (MacMilan et al., 2003).

3. Strategic management includes recognition of necessary balance (trade-off) between effectiveness and efficiency.

Robert Monks and Nil Minow, define corporative management as a link between different stakeholders who take part in directions and performances of a corporation (Berkowitz, 2000).

\subsection{ICT based strategic management}

The strategy of an organization has been connected to the application of technologies (particularly new technologies) in a number of cases in organizations. One of the better known examples is the typology by Miles et al, dividing companies in investigators, prospectors, defenders and reactors, among other things also on the basis of the relationship that a company has towards new technologies (1978). It is not only that the strategic orientation determines the priorities (e.g., human resources, technology, financial position, market positioning) towards whose improvement organizations will try to focus its operational efforts, but also the modalities of improvements and development of these aspects (Čudanov, 2006). "The ICT Strategy considers more than just technology solutions, and demonstrates an understanding of the people, process, information and technology components required to deliver the business objectives" (Deloitte, 2010, p. 5). Both the ICT Strategy and the organization's business objectives are aligned. The ICT Strategy demonstrates a clear linkage from the Business Strategy through the related business requirements and the supporting ICT requirements (Deloitte, 2010). According to Podolsky (2003), when an organization decides to implement new technology it is asking its employees and key stakeholders to adapt to new tools, processes, and policies that are likely to be very different from the ones they have grown accustomed to. To some authors, "Communication is the most important element in managing organizational change" (Podolsky, 2003, p. 255). Some authors believe that "Strategic sourcing is the dynamic delivery of internal and external business or IT oriented resources and services 
to ensure that business objectives are met" (Da Rold et al., 2002, p. 5). According to Da Rold et al (2002, p. 222), "IT Strategy examines how IT can support the objectives set by the business strategy". IT Strategy overlaps and fuses with the business strategy. The objective of information gathering and processing, planning, coordination and control "just"- in Union matters at the super national level. This process will lead to convergence of national public administrations (Schwarze, 2008). For some authors, creating a technology plan is an opportunity for an organization to focus on its mission, goals and strategies - "A technology that focuses on mission is most likely to outline technology that facilitates improvements in the organization" (Podolsky, 2003, p. 5). According to Sabherwal and Chan (2001), the strategic determination of the so called prospectors and analyzers require greater application of ICT and strategy development of the IT system that must be in line with the business strategy. In previous papers, especially in the researches that have been done by Henderson and Varkrataman (1993), the two-way connection between the general strategy of an organization and the strategy which is bound to the ICT subsystem in an organization is obvious. "It is useful to start a Strategy with a Vision of ICTs role in enabling the delivery of policing. This must consist of a Statement or a short list of the priorities. To some authors, new technologies are the ones of the most important paths toward corporation entrepreneurship - "But the technologies change and the innovations that were exiting yesterday are already out of date today" (Lumpkin et al, 2007, p. 434). Hence, "This should align closely with the business objectives contained with the organization's Business Strategy and any other strategic plan" (Deloitte, 2010, p. 6). The innovations are one of the most important sources where convenient business opportunities are being born. An innovation means use of new knowledge with an aim to transform organizational processes. The sources of new knowledge encompass the latest technology, results of experiments, results of creative researches or information about competitors. Innovations are combinations of ideas and information that bring positive changes (Lumpkin et al, 2007). The strategy determines the implementation of information and communication technologies. It is important to point out that it cannot be considered one way, because the implementation of ICT has a retroactive impact on the strategy of an organization (Čudanov, 2006). ICT is increasingly used for strategic purposes. According to the research done by Nelson Oly Ndubisi (2003), the strategic significance and impact of ICT are also connected to a group of tasks that are mostly operational. Simple, everyday tasks that are performed using IS increase the value of the system. For some authors, formulation of a strategy of organization encompasses: formulation of strategy on organizational unit level, formulation of strategy on an organization/company level, formulation of international strategy and strategy of digital business. Digital technologies change business processes and management within organizations. Successful application of digital technologies can assist organizations to improve their position on the (global) market and to create an advantage by improving leadership strategy in cost management and strategy of business differentiation (Lumpkin et al., 2007) - "New technologies are the most important sources of new strategy ideas" (Lumpkin et al., 2007, p. 436). 


\section{MATERIALS AND METHODS}

\subsection{Research methodology}

This research used quantitative and qualitative approach. Patton (2002) has argued that a qualitative research methodology can help researchers approach fieldwork without being constrained by any predetermined categories of analysis.

Moreover, Gay, Mills and Airasian (2009) explained that the strength of quantitative research is the opportunities that it provides researchers to interact and gather data directly from their research participants to understand a phenomenon from their perspectives. On the other hand, qualitative research carries the uniqueness because it does not give conclusion in advance. It is often regarded as a scientific methodology of management sciences research (Taylor, 1998).

\subsection{Sample structure and size}

In the research, data were collected by having an insight into the secondary data (customs reports and interviews with the top management) and through a survey (questionnaire). In order to achieve the objectives of the research, 50 questionnaires were distributed among the managers of the customs houses in Serbia, 25 for the experimental group and another 25 for the control group. In response 21 questionnaires were returned from the experimental group and 20 for the control group. The response rate was $82.2 \%$ for both groups. Among all managers who were respondents, 41 of them or $100 \%$ were convenience and fixed sample. There were 21 customs house manager after the NTCS had been introduces (experimental group) and 20 customs house managers, before the NCTS had been introduces (control group). According to some authors, the control group consists of elements that present exactly the same characteristics of the experimental group, except for the variable applied to the latter. This group of scientific control enables the experimental study of one variable at a time, and it is an essential part of the scientific method. In a controlled experiment, two identical experiments are carried out: in one of them, the treatment or tested factor (experimental group) is applied; whereas in the other group (control), the tested factor is not applied (Kinser \& Robins, 2013).

Table 1 The structure of the samples

\begin{tabular}{lcc}
\hline Variable & Number of respondents & $\%$ \\
\hline Experimental group & 21 & 51.2 \\
Control group & 20 & 48.8 \\
The NCTS & & \\
$\quad$ Yes & 21 & 51.2 \\
$\quad$ No & 20 & 48.8 \\
& & $\mathrm{~N}=41$ \\
\hline
\end{tabular}

\subsection{Instrument}

Apart from the personal interviews, the questionnaire was designed on Likert 5 Rating Scale $(1=$ Strongly Disagree, $2=$ Disagree, $3=$ Neutral, $4=$ Agree and 5=Strongly Agree) . To test the impact of the variables the data were analyzed through SPSS. The survey 
included grades of the managers' attitudes measured by 5-point Likert scale about the improvement of the KPIs: quality of checks, collection of revenues, cost and expenditure management and reputation and competiveness.

\subsection{Data collection}

The required information for the research was collected through questionnaire, personal interviews with the top managers and on-line interviews with the customs houses managers. The data was also collected from the customs statistics and reports - secondary data.

\subsection{Methods}

The creation of diagrams is used in this research in order to analyze Stakeholders Analyzes - SWOT and Strategy and Strategic Risk Assessment Rating ("3x3" risk matrix) based on the data collected by interview and by secondary data. Descriptive statistics was used to measure the difference of the managers' perceptions of improvement of the KPIs after the NCTS had been introduced (the experimental group) and the managers who did not operate in line with the NCTS (the control group), that is shown in the Table 2. Encompassed metrics were grouped into four clusters-KPIs: quality of trans-border prevention, collection of revenue, cost and expenditure management and reputation and competiveness. For Cole (2006), organizations must ensure that strategy and operations are articulated.

Table 2 CH managers' perception and measurement of the KPIs

\begin{tabular}{|c|c|c|c|c|c|}
\hline & & \multicolumn{2}{|c|}{ Experimental group } & \multicolumn{2}{|c|}{ Control group } \\
\hline & & $\mathrm{M}$ & SD & $\mathrm{M}$ & $\mathrm{SD}$ \\
\hline KPI1 & Quality of trans-border prevention & & & & \\
\hline S1 & Quality of checks & 4.70 & 0.470 & 4.38 & 0.498 \\
\hline S2 & Level of prevention of smuggling of goods & 4.75 & 0.444 & 4.43 & 0.507 \\
\hline S3 & $\begin{array}{l}\text { Level of prevention of false clearance } \\
\text { (forged and stolen stamps) }\end{array}$ & 4.70 & 0.470 & 4.19 & 0.402 \\
\hline S4 & Level of efficient targeting for inspection & 4.80 & 0.410 & 4.38 & 0.498 \\
\hline KPI2 & Revenue collection improvement & & & & \\
\hline S5 & Collection of excise & 4.70 & 0.470 & 4.38 & 0.498 \\
\hline S6 & Collection of customs duties & 4.65 & 0.489 & 4.33 & 0.483 \\
\hline S7 & Collection of fines & 4.85 & 0.366 & 4.48 & 0.512 \\
\hline KPI3 & $\begin{array}{l}\text { Contribution to cost and expenditure } \\
\text { management }\end{array}$ & & & & \\
\hline S8 & Facilitation of flow of goods/trucks & 4.80 & 0.410 & 4.38 & 0.498 \\
\hline S9 & Efficient allocation of staff & 4.65 & 0.489 & 4.14 & 0.359 \\
\hline S10 & Efficient allocation of technical resources & 4.45 & 0.510 & 4.19 & 0.602 \\
\hline KPI4 & $\begin{array}{l}\text { Contribution to overall reputation and } \\
\text { competiveness }\end{array}$ & & & & \\
\hline S11 & $\begin{array}{l}\text { Reputation among other customs } \\
\text { administrations }\end{array}$ & 4.65 & 0.489 & 4.24 & 0.539 \\
\hline $\mathrm{S} 12$ & Reputation in the eye of public & 4.85 & 0.366 & 4.48 & 0.512 \\
\hline S13 & $\begin{array}{l}\text { Competiveness with the neighboring } \\
\text { corridors }\end{array}$ & 4.70 & 0.470 & 4.38 & 0.499 \\
\hline
\end{tabular}


The Independent Sample T-test is used to confirm the existing difference between the experimental and the control group related to KPIs, such as: quality of trans-border prevention, improvement of revenue collection, cost and expenditure management and overall reputation and competiveness (Table 3 ).

Table 3 (Significant) differences in the evaluations of KPIs: experimental vs. control group

\begin{tabular}{llc}
\hline & & $\mathrm{p}$ \\
\hline S1 & Quality of checks & 0.042 \\
S2 & Prevention of smuggling of goods & 0.037 \\
S3 & Prevention of false clearance (forged and stolen stamps) & 0.001 \\
S4 & Efficient targeting for inspection of goods & 0.006 \\
S5 & Collection of excise & 0.042 \\
S6 & Collection of customs duties & 0.044 \\
S7 & Collection of customs fines & 0.011 \\
S8 & Facilitation of flow of goods/trucks & 0.006 \\
S9 & Efficient allocation of staff & 0.001 \\
S10 & Efficient allocation of technical resources & 0.145 \\
S11 & Reputation among other customs administrations & 0.015 \\
S12 & Reputation in the eye of public & 0.011 \\
S13 & Competiveness with neighboring countries corridors & 0.042
\end{tabular}

Independent sample T-test - significance level $\mathrm{p}<0.05$

\section{DISCUSSION}

According to the secondary data (an insight into the reports) and personal interviews with the top management, the research results show that the Customs Service conducts a SWOT and Strategy Analysis (as shown in the Diagram 1) that follows the Strategic Risk Assessment Rating (as shown in the Diagram 2). For Cole (2007), the most important factor of external influences on public administrations apart from Political, Economic, and Social is Technology (especially technological advances). Hence, public administrations apply PEST Analysis.

According to the results of the research based on secondary data collected, the Customs Service deals with, according to Cole (2007), indirect stakeholders (i.e., those not necessarily engaged in direct transactions, but nevertheless significantly affected by the services' activities: 1. the community (local, regional, national or international); 2 . competitors (i.e., those organizations providing similar services); 3. the government (i.e., those charged with the management of the economy as a whole on behalf of the community).

Based on the analysis of the secondary data, the research results show that the Customs Service faces the external influences such as: 1 . Supra - national bodies, that are according to Cole (2006) organizations which exert their influence outside that of national governments and sometimes overrule the latter, 2. Government and the Law - Customs Service " is affected by changes in indirect and direct Taxation Law, health and safety and environmental factors" (Cole, 2006, p. 31). 


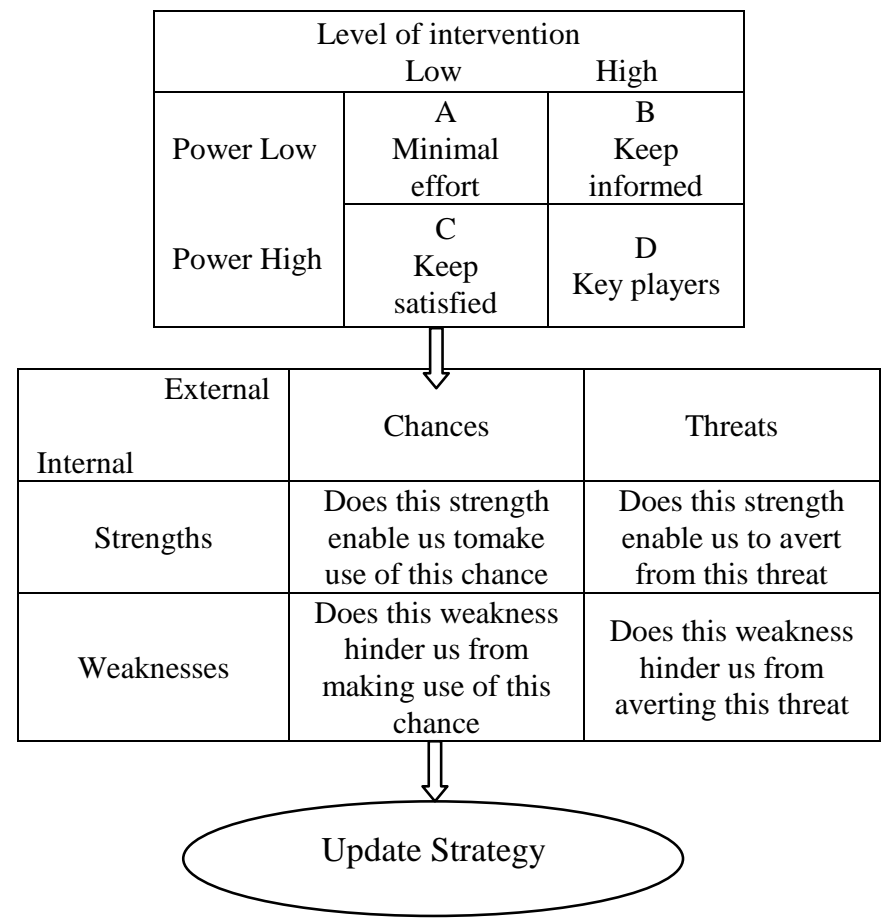

Fig. 1 Stakeholders Analysis - SWOT and Strategy

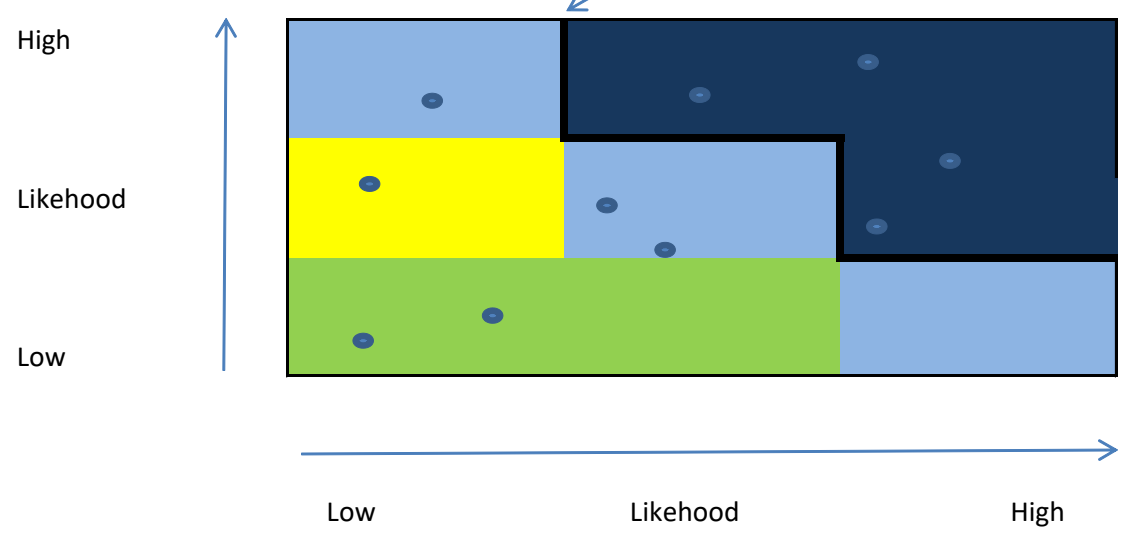

Fig. 2 Strategic Risk Assessment Rating (“3x3” risk matrix) 


\subsection{Evaluation of the KP1 - quality of trans-border prevention}

The results of the descriptive statistics in this research show that the experimental group evaluated the statement related to efficient targeting of consignments for inspection with the Mean of 4.80 and the standard deviation of 0.410 better than the prevention of smuggling of goods with the Mean of 4.75 and the standard deviation of 0.444 . The third ranked statements are quality of checks and prevention of false clearance (forged and stolen stamps), both with the Mean of 4.70 and the standard deviations of 0.470 . On the other hand, the control group evaluated the statement related to prevention of smuggling of goods with the Mean of 4.43 and the standard deviation of 0.507 that is better than the quality of check and efficient targeting of consignments for inspection with the Means of 4.38 and the standard deviations of 0.498 , as well as prevention of false clearance (forged and stolen stamps) with the Mean of 4.19 and the standard deviation of 0.402 (Table 2). It can be concluded that the officers evaluated the statement related to the targeting of consignments for inspection as the best improved. The Independent Sample T-test results (Table 3) also show that there is a significant difference in evaluation of quality of checks between the experimental and the control groups $(\mathrm{p}=0.042)$, prevention of smuggling of goods $(\mathrm{p}=0.037)$, prevention of false clearance (forged and stolen stamps) $(\mathrm{p}=0,001)$ and efficient targeting of consignments for inspection $(\mathrm{p}=0.006)$.

\subsection{Evaluation of the KPI2 - collection of revenues}

Regarding the results of the descriptive statistics data analysis in this research shows that the experimental group evaluated collection of customs fines with the Mean of 4.85 and the standard deviation of 0.366 , that is better than collection of excise duties with the Mean of 4.70 and the standard deviation of 0.470 and collection of customs duties with the Mean of 4.65 and the standard deviation of 0.489 . The control group also evaluated collection of fine with the Mean of 4.48 and the standard deviation of 0.512 better than collection of excise with the mean of 4.38 and the standard deviation of 0.498 and collection of customs duties with the Mean of 4.33 and the standard deviation of 0.483 , meaning that, the officers evaluated a proportional and linear improvement of the performance related to the KPI of collection of revenue (Table 2). According to the Independent Sample T- test analysis (Table 3), there is a significant difference in evaluation of collection of excise duties $(\mathrm{p}=0.042)$, a significant difference in evaluation of collection of customs duties $(\mathrm{p}=0.044)$, as well as a significant difference in evaluation of collection of the customs fines $(\mathrm{p}=0.011)$, that can confirm our hypothesis that the NCTS has a significant impact on the KPI related to collection of revenue.

\subsection{Evaluation of the KPI3 - cost and expenditure management}

The research results from the descriptive statistics data analysis show that the experimental group evaluated facilitation of the flow of goods/trucks with the best grades, with the Mean of 4.80 and the standard deviation of 0.410 . The second best ranged is efficient allocation of staff with the Mean of 4.65 and the standard deviation of 0.489 which is better evaluated than the efficient allocation of resources with the Mean of 4.45 and the standard deviation of 0.510 . The control group evaluated facilitation of the flow of goods/trucks as the best ranged as well, with the Mean of 4.38 and the standard 
deviation of 0.498 . The second best ranged is efficient allocation of resources with the Mean of 4.19 and the standard deviation of 0.602 . The third best ranged is efficient allocation of staff, with the Mean of 4.14 and the standard deviation of 0.359 (Table 2). According to the Independent Sample T- test analysis, there is not a significant difference in evaluation facilitation of the flow of goods/trucks $(p=0.006)$ and a significant difference in evaluation of allocation of staff $(\mathrm{p}=0.001)$, but there is not a significant difference in evaluation of efficient allocation of technical resources $(p=0.145)$. Thus, these evaluations partially confirm our hypothesis that the NCTS has a significant impact on the KPI related to cost and expenditure management.

\subsection{Evaluation of the KPI4 - overall reputation and competitiveness}

The research results according to the descriptive statistics data analysis show that the experimental group evaluated the reputation in the eye of general public with the Mean of 4.85 and the standard deviation of 0.366 better than the competitiveness with the neighboring corridors, with the Mean of 4.70 and the standard deviation of 0.470 and the reputation among the other customs administrations, with the Mean of 4.65 and the standard deviation of 0.489 . The control group also evaluated the reputation in the eye of the general public as the best ranked, with the Mean of 4.48 and the standard deviation of 0.512 better than the competitiveness with the neighboring corridors, with the Mean of 4.38 and the standard deviation of 0.499 and reputation among other customs administrations, with the Mean of 4.24 and the standard deviation of 0.539. According to the Independent Sample Ttest analysis (Table 3), there is a significant difference in evaluation of reputation among other customs administrations ( $\mathrm{p}=0.015)$, a significant difference in evaluation of reputation in the eye of general public $(\mathrm{p}=0.011)$ and a significant difference in evaluation of competitiveness with the neighboring corridors $(\mathrm{p}=0.042)$. Thus, the evaluations confirmed our hypothesis that the NCTS improved the KPI related to reputation and competition.

\section{CONCLUSION}

Establishment of open but well secured borders, better control of revenue collection and improvement of competitiveness and overall reputation are the main goals of the Serbian Customs Administration. For Cole (2006), the key goals or aims of the organization usually embrace the major units or functions of the organization. The research results showed that the establishment of ICT enabled the implementation of the Strategy of the Customs Administration top management and therefore improved the main KPIs. Some authors argue that the role of this new process is continuously developing of key operational processes, hence the achievement of target values of process KPIs (Komazec et al., 2014). Talking about the needs of implementation of strategies within customs administrations, we can also refer to the phenomenon of globalization, to the significant increase of the number of the member states, to the energy and environmental problems and to the fight against terrorism (Schwarze, 2008). To some authors, "Organizations which want to maintain a competitive advantage have to be ready to adopt and adapt technological developments in administrative procedures to stay ahead" (Cole, 2006, p. 31). ICT enabled implementation of Strategy of the Customs Service of Serbia is primarily based on data exchange with the stakeholders, hence, the Mission Statement of the Customs is technical 
collaboration (Cole, 2006). On the basis of the aforementioned we can draw a conclusion that the creation of the area without borders, a single geographical area is the future of the European Administrative Space (Torma, 2011).

This research contributed to confirm the hypothesis that the introduction of ICT system enabled the top management of the Serbian Customs Service to implement the Strategy and hence improve the operational results in general. The other benefit is that this is one of the first researches related to ICT based Strategy implementation of the CAS.

The disadvantages of this research are the fact that questionnaire method has several limitations, for example lackadaisical attitude of respondents, non-attendance and lack of cooperation. One more limitation of the research is the fact that it did not involve all the crossing points in Serbia and possibly insufficient number of samples, which is reserved for some of oncoming related researches.

\section{REFERENCES}

Berkowitz, E.N. (2000). Marketing. $6^{\text {th }}$ edition, New York: McGraw-Hill.

Bouman, K. (2003). Strategy in Practice. England, Essex: Pearson Education Limited.

Chatterjee, S. (2005). Core objectives: clarity in designing strategy. California Management Review, 47 (2), 33-49.

Cole, G.A. (2006). Strategic Management - Theory and Practice. $2^{\text {nd }}$ edition, UK, London: Thomson Learning.

Čudanov, M. (2006). Design of the organization in terms of the progress of information and communication technologies and systems. Serbia, Belgrade: The Faculty of Organized Sciences. (in Serbian).

Da Rold, C., Grigg, J, \& Berg, T. (2002). How to Build a Sourcing Strategy - Strategic Analysis Report. UK, London: Gartner Research.

Deloitte (2010). Developing an Effective ICT Strategy - Guidance in Assessing an ICT Strategy. New York: Deloitte Publishing.

Gay, L. R.., Mills, G. E., \& Airasian, P. (2009). Educational research: Competencies for analysis and applications. UK, London: Pearson.

Gupta, A.K., \& Govindarajan, V. (2001). Converting global presence into global competitive advantage. Academy of Management Executive, 15 (2), 45-56.

Henderson, J.C., \& Venkatramann, N. (1993). Strategic alignment: Leveraging information technology for transforming organizations. IBM Systems Journal, 32 (1), 4-16.

Hiriyappa, B. (2013). Strategic Management and Business Policy - For Managers and Consultants. IN, Bloomington: Booktango.

Kinser P.A., \& Robins J.L. (2013). Control group design: enhancing rigor in research of mind-body therapies for depression. Evid-Based Complement Alternat Med, 140-467.

Komazec, S., Todorović, I., \& Jaško, O. (2014). Standardization of Process Management as a Tool for Introducing the Process Approach to Organization. In Mijatović, I., Filipović, J., Horvat, A. (Ed.) Proceedings of 11th International Conference "Standardization, Prototypes and Quality: A Means of Balkan Countries' Collaboration". Belgrade, Serbia: Faculty of Organizational Sciences, 65-73. ISBN: 978-86-7680-299-9.

Lu, J.W., \& Beamish, P.W. (2004). International diversification and firm performance: s-curve hypothesis. Academy of Management Journal, 47(4), 598-609.

Lumpkin, G.T., Dess, G.D., \& Eisner, A.B. (2007). Strategic Management - Theories and Cases. Serbia, Belgrade: Data Status. (in Serbian).

MacMilan, I.C., van Putten, A.B., \& McGrath, R.G. (2003). Global gamesmanship. Harward Business Review, $81(5), 62-73$.

Oly Nolubisi, N. (2003). Understanding strategic use of IT in small \& medium sized businesses: Examining push factors and user characteristics. Academy of Information and Management Sciences Journal, 6 (1).

Patton, M. Q. (2002). Qualitative research \&evaluation methods. Thousand Oaks, CA: Sage Publications.

Podolsky, J. (2003). Wired for Good - Strategic Technology Planning for Nonprofits, USA, CA, San Francisco: Jossey-Bass. 
Sabherwal, R., \& Chan, Y.E. (2001). Alignment between business and IS Strategies: A study of prospectors, analyzers and defenders. Information System Research, 12 (1), 11-33.

Schwarze, J. (2008). (ed.): Bestand und Perspektiven des Europaischen Verwaltungsrechts. Germany, BadenBaden: Nomos Verlag. (in English).

Stross, R.E. (1997). Gates builds his brain trust. Fortune, December 8, 84-98

Taylor, S. J., \& Bogdan, R. (1998). In-depth interviewing. Introduction to qualitative research methods: a guidebook and resource, 87-116.

Torma, A. (2011). The European Administrative Space (EAS). European Integration Studies, 9 (1), 149-161.

\section{IMPLEMENTACIJA STRATEGIJE OMOGUĆENA IKT-OM - EMPIRISKI DOKAZ IZ CARINSKE SLUŽBE SRBIJE}

U ovom radu predstavljena je implementacija Strategije Carinske službe Srbije omogućena IKTom. Cilj istraživanja je merenje $i$ analiza uticaja IKT-a na uspešnu implementaciju strtaegije organizacije. Istraživanje je sprovedeno anketom - upitnici i lični intervjui sa višim rukovodstvom $i$ generalnim direktorom. Podaci su takođe prikupljeni uvidom u sekundarne podatke (carinski izveštaji). Rezultati istraživanja pokazuju da novi kompjuterizovani sistem ima pozitivan uticaj na poboljšanje ključnih indikatora performansi (KPI), što predstavlja suštinski cilj Strategije.

Ključne reči: strategija, informaciona i komunikaciona tehnologija, strategijski menadžment 